\title{
SETTLEMENT OSCILLATIONS IN THE NEGEV HIGHLANDS REVISITED: THE IMPACT OF MICROARCHAEOLOGICAL METHODS
}

\author{
Ruth Shahack-Gross
}

Kimmel Center for Archaeological Science, Weizmann Institute of Science, Rehovot 76100, Israel. Corresponding author. Email: ruth.shahack@weizmann.ac.il.

\section{Israel Finkelstein}

The Jacob M. Alkow Department of Archaeology and Ancient Near Eastern Civilizations, Tel Aviv University, Tel Aviv 6997801, Israel.

\begin{abstract}
Microarchaeological methods, especially those focused on geoarchaeology and radiocarbon dating, have revolutionized the manner in which the Iron Age settlement peak in the Negev Highlands is interpreted. We review here results from field and laboratory studies conducted at two Iron Age sites (Atar Haroa and Nahal Boqer) compared to one Byzantine/ Early Islamic site (Wadi el-Mustayer) — all located near Sede Boqer. We present our methodology, which is based on smallscale but detailed excavations, study of sediments, and identification of livestock dung remains and their utility as indicators of past subsistence practices. To this we add meticulous ${ }^{14} \mathrm{C}$ dating, ceramic petrography, and identification of botanic and zoological remains. We conclude that subsistence during the Iron Age included tending livestock but did not include agriculture. We further propose that the long-distance trade of copper from the Arabah Valley under Egyptian auspices and possibly the trading of cinnamon, dates, and other Arabian/Indian commodities were the driving force in the initiation (and later decline) of the Iron Age settlement system. We hypothesize that the agricultural settlement peak during the Byzantine/Early Islamic period was also influenced by an imperial power from outside of the Negev and that large-scale agriculture was enabled due to the adoption of new agricultural techniques, including terracing of ephemeral streams along with water diversion systems and possibly water storage facilities such as advanced cisterns. Future studies are expected to shed additional light on the complexity of settlement oscillations in the Negev Highlands region in key periods such as the Early and Intermediate Bronze Ages.
\end{abstract}

\section{INTRODUCTION}

Intensive archaeological explorations - surveys and excavations alike - have identified four main settlement periods in the Negev Highlands, an arid zone in southern Israel. Using ceramic typology, these periods were assigned to the Early Bronze Age II, Intermediate Bronze Age (also known as Early Bronze IV), Iron Age IIA, and Byzantine/Early Islamic Period culture-historical complexes. Other periods in the same region that span long eras, such as the Middle and Late Bronze Ages and most of the Iron Age, are not represented archaeologically. Sharp settlement oscillations thus characterize the history of the Negev Highlands (Rosen 1987; Finkelstein 1995 and references therein).

Possible reasons for these settlement oscillations have been discussed at length. Because the Negev Highlands is an arid region ( $\sim 100 \mathrm{~mm}$ of annual rainfall), one theory proposed that, among other factors, populations moved in and out of the area in relation to changing environmental/climatic conditions (e.g. Rosen 1987). Water availability in the region is indeed a limiting factor for human subsistence, with low potential for agriculture and even for animal husbandry. Others considered these demographic oscillations to be related to socioeconomic opportunities and geopolitical changes (e.g. Finkelstein 1995; Haiman 1996 and references therein). A third explanation is that periods of settlement took place in relation to improved economic opportunities. One example is participation of local groups in copper production in the Arabah Valley and transportation of copper to Egypt and other places in the ancient Near East (e.g. Levy 2009; Martin et al. 2013). Another example is the transportation of lucrative south Arabian commodities, such as myrrh and frankincense, through the region in the same direction (e.g. Finkelstein 1988; Jasmin 2006). These activities were at least partially related to the balance of power between empires and kingdoms that surrounded the Negev, e.g. Egypt, Assyria, Rome, and Byzantium as well as Israel, Judah, and Edom.

Still, a key question is the daily mode of subsistence of the Negev Highlands inhabitants during the peak settlement periods: Were they engaged in primary production of agricultural and herd

The Iron Age in Israel: The Exact and Life Sciences Perspective

Edited by Israel Finkelstein, Steve Weiner, and Elisabetta Boaretto 
products, did they rely on exchange (and/or purchase) of commercial goods, or conduct a complex regime of both? Determining the subsistence mode is crucial for understanding each of the historical peaks of human activity in the region, as well as the broader phenomenon of settlement oscillations over time. Related issues that may influence the interpretation of the settlement oscillations and their historical background are the exact dating of the sites and past climate/environmental conditions.

Most previous studies in the Negev Highlands inferred subsistence practices using traditional archaeological methods, focused on macroscopically visible remains only (systematic studies of faunal and botanical remains were not conducted). Researchers deduced herding from stone structures interpreted as animal pens, agriculture from stone walls along ephemeral streams (i.e. wadi terraces) as well as grinding stones and sickle blades, and copper trade from occasional finds of copper ingots or objects. The prevailing assumption has thus been that the Negev Highlands inhabitants in the Iron Age and later periods engaged in animal husbandry and small-scale seasonal agriculture (e.g. Haiman 1989; Finkelstein 1995; Cohen 1999; Cohen and Cohen-Amin 2004). With the exception of wadi terraces (Goldberg 1984; Bruins 1986; Bruins and van der Plicht 2005; Avni et al. 2006, 2012), none of these features has been studied in detail. Also, all sites and features representing a given settlement peak were described as belonging to a single wave of activity, although in most cases these remains could not be accurately dated. Hence, minute chronological differences within the peak periods (for the Early Bronze Age, see e.g. Sebbane et al. 1993) and the relationship between remains (e.g. associating datable pottery from a built site with undated wadi terraces in its vicinity; see an example of such a mistaken association in the Nahal Zena "fortress" site in Avni et al. 2009) could not be traced. In addition, cases where terraces were dated based on reworked charcoal associated with terrace fill sediments (e.g. Bruins and van der Plicht 2005) is highly questionable. Therefore, both the period-by-period interpretation and the overall, long-term, socioeconomic reconstruction of human activity in the Negev Highlands have been based on partial data.

With the development of research into the microscopic archaeological record (hereafter microarchaeology, sensu Weiner 2010) it became clear that crucial data required for connecting subsistence economy, specific time periods, and environment in the Negev Highlands sites may be obtained by deploying these methods.

\section{THE MICROARCHAEOLOGICAL PROJECT IN THE NEGEV HIGHLANDS}

Research of the microscopic record in various locations and chronological contexts has shown that certain materials hold information that allows identifying the subsistence base of ancient groups, as well as subsistence interrelationships between ancient groups. For example, identification of thick accumulations of dung deposits indicates presence of livestock enclosures and thus herding of animals (Shahack-Gross et al. 2003; Shahack-Gross 2011), and use of elemental analysis in lithic, ceramic, and metal object studies enables identification of traded items and trade routes (see Weiner 2010:36-40 on "provenience and procurement strategies"; Segal et al. 1996-1997; Martin et al. 2013 for the Negev Highlands). Here, we review the contribution of microarchaeological studies to deciphering the nature of the Iron Age settlement peak in the Negev Highlands. Our project, ongoing since 2005, focuses on full retrieval of information related to subsistence and chronologymacroscopic and microscopic - and is designed to incorporate the aspect of paleoclimate/environment in the near future as well.

The first stage of the project focused on the Iron Age settlement peak, which is restricted to a short phase in this period, mainly in the Iron IIA (e.g. Herzog and Singer Avitz 2004). We worked at two sites - Atar Haroa and Nahal Boqer - both located in the area of Sede Boqer, $\sim 50 \mathrm{~km}$ south of Beer Sheba (Figure 1). Our work included two aspects of microarchaeological research: geoarchaeology 
and radiocarbon dating. We attempted to answer the question of subsistence strategies by employing methods that examine microscopic remains indicative of animal dung. This material, if properly identified, holds a wealth of information about the foddering practices of ancient herdsmen, and is especially useful in differentiating pastoral from agropastoral groups (see Shahack-Gross 2011 for a review of additional types of information that can be obtained from archaeological remains of livestock dung). The geoarchaeological aspect was thus composed of two parts: methodology development and archaeological application. The former included building a database of the phytolith component in selected Negev Highlands fodder plants and a database of the phytolith and dung spherulite components, as well as $\delta^{15} \mathrm{~N}$ and $\delta^{13} \mathrm{C}$ values in dung from various modern Negev Highlands wild and domestic herbivores (Shahack-Gross and Finkelstein 2008). In addition, we tested the state of preservation of phytoliths in the Negev Highlands (Shahack-Gross et al. 2014). The archaeological application segment of the project was achieved through fieldwork at the two Iron IIA sites, where systematic sampling of sediments for studying subsistence practices and charred botanical remains for ${ }^{14} \mathrm{C}$ dating were conducted (Shahack-Gross and Finkelstein 2008; Boaretto et al. 2010; Shahack-Gross et al. 2014). Fieldwork was carried out via small-scale excavations. Two rooms and three courtyard contexts were opened at Atar Haroa, while at Nahal Boqer the contexts of one room and one courtyard were investigated (for location of excavation contexts, their sizes and types and numbers of samples, see Shahack-Gross and Finkelstein 2008; Shahack-Gross et al. 2014). We have been criticized in the past for sampling in the courtyard contexts; however, these contexts are exactly those where remains of animal corralling, and the information they include about foddering practices, were expected (and found; see below). Additionally, we tested our results against two control situations in the same region: (a) an abandoned, pre-modern Bedouin rockshelter and (b) a Byzantine/Early Islamic site (see details in Shahack-Gross et al. 2014).

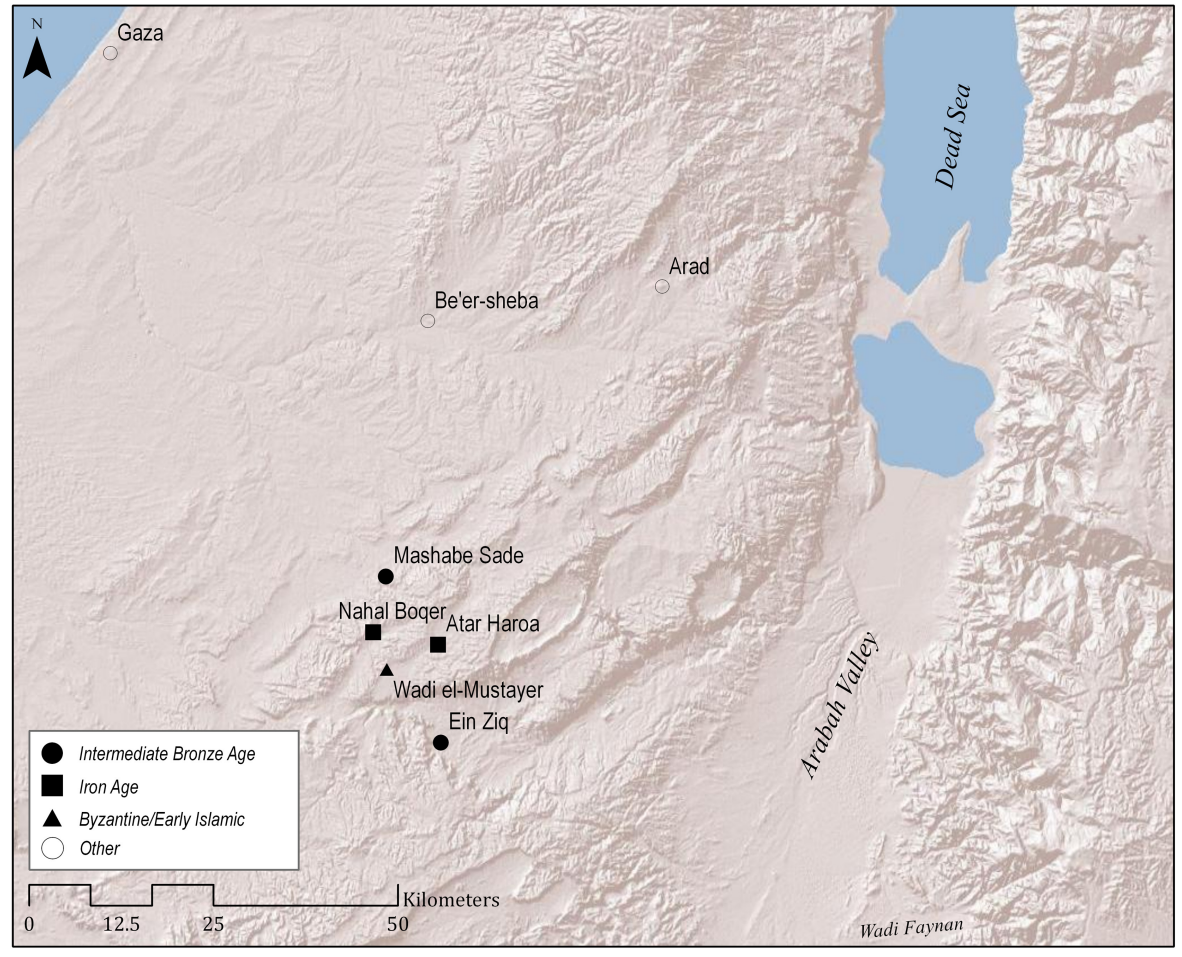

Figure 1 Location of sites mentioned in the text (open circles: Bronze and Iron Age urban sites close to the study region); note the location of the studied sites in relation to the Arabah Valley and Wadi Faynan. 
All of this work provided a set of new and surprising insights on animal husbandry practices, on the date of the sites, and on commercial ties with neighboring regions, resulting in several significant paradigm changes:

1. It was found, using micromorphology and phytolith analysis, that the inhabitants of the Iron Age sites were herding animals but did not engage in cereal cultivation, contrary to previous "common wisdom" (Shahack-Gross and Finkelstein 2008; Shahack-Gross et al. 2014). We discuss critiques of this conclusion in greater detail below.

2. While previous studies promoted the idea that the Iron Age sites were 10th century BCE Judahite royal fortresses that were destroyed by Pharaoh Shoshenq I in his campaign to Canaan $\sim 925$ BCE (e.g. Cohen 1979; Haiman 1994), our ${ }^{14} \mathrm{C}$ assays have proven that the sites were occupied mainly after this campaign (late 10th to late 9th centuries BCE; Figure 2). This indicates that the settlements flourished rather than declined following this event, during a period of Egyptian domination in the region, which was probably related to the copper industry in the nearby Arabah Valley (Boaretto et al. 2010; Shahack-Gross et al. 2014; for Egyptian influence in the Arabah copper sites see Ben-Yosef 2010:971-8).
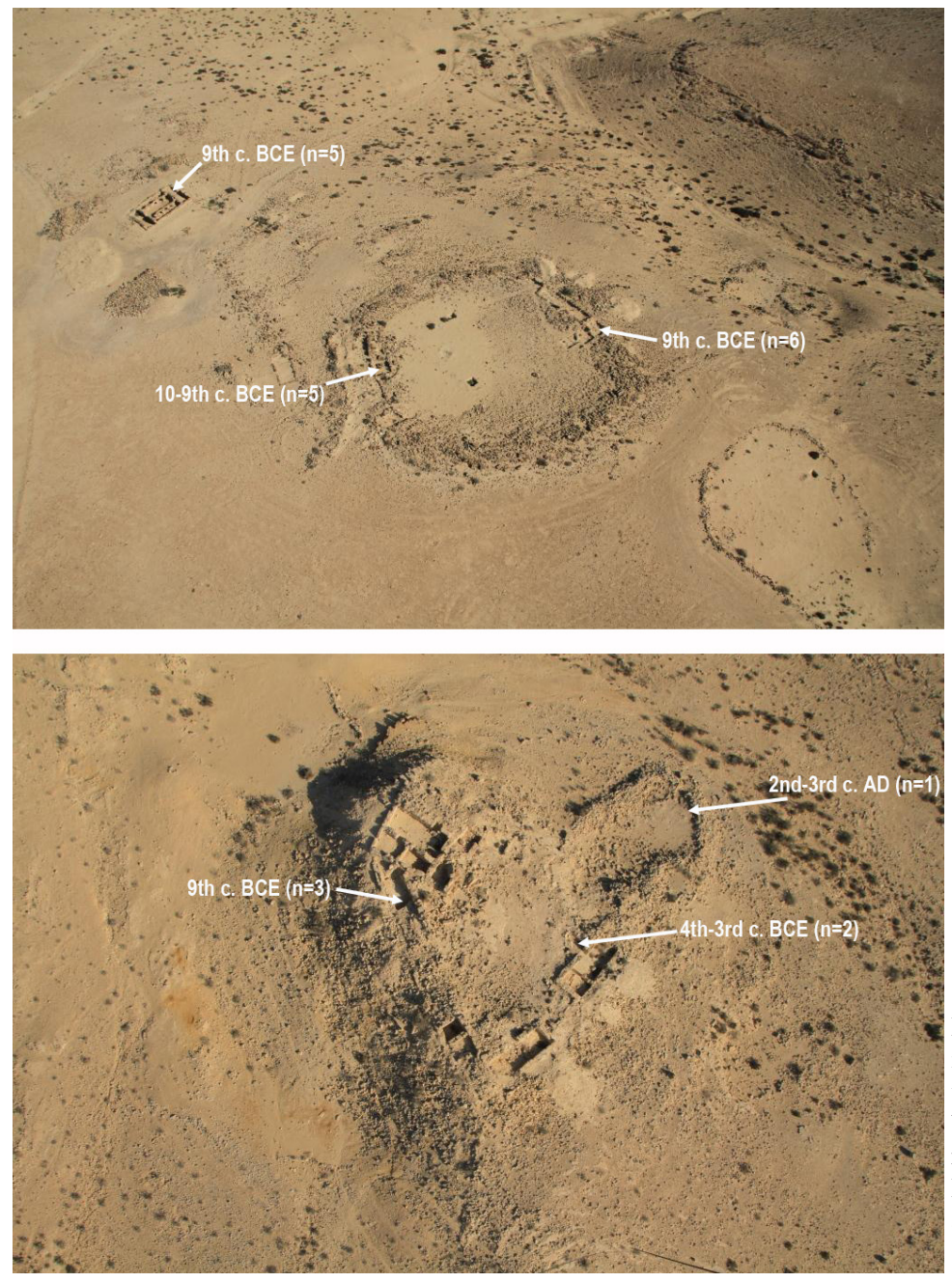

Figure 2 Aerial photographs showing the two Iron Age sites studied, with reference to location and number of ${ }^{14} \mathrm{C}$ samples and to the general results. Top: Atar Haroa; bottom: Nahal Boqer. The Iron Age activity at both sites is limited to the late 10th to late 9th centuries BCE. 
3. We have shown that the sites studied by us were not destroyed by fire, as suggested in past research (Cohen 1979); rather, the black-gray dusty layer of sediment on floors originated from partially degraded livestock dung (Shahack-Gross and Finkelstein 2008). Additionally, we identified fragments of mudbrick, revealing information thus far unknown on the construction technology of these settlements.

4. We identified that fuel materials for hearths within rooms were local, including wood from trees and shrubs (e.g. Tamarix and Retama species) as well as livestock dung (Shahack-Gross and Finkelstein 2008). The latter component is another support for the pastoral nature of the settlements. Additionally, we identified charred seeds of date palm, barley, grape, and chickpea (Boaretto et al. 2010).

5. Despite the lack of macroscopic copper remains, ceramic petrography identified copper slag that was incorporated as temper into the typical "Negebite" pottery that is found in abundance in the Iron IIA sites in the Negev Highlands. This finding provides evidence for a link between the Negev Highlands and the copper production areas in the Arabah (Martin et al. 2013).

Our first conclusion, about lack of evidence for cereal cultivation in the Iron Age, has been criticized in the past, in personal communication following presentation of results at international and national scientific meetings and through comments made by the two readers of this review article. The evidence produced in our studies is based on the identification of thick accumulations of degraded dung deposits at Atar Haroa (about 10-20 cm thick, indicating that the organic component formed much thicker deposits) and Nahal Boqer (Shahack-Gross and Finkelstein 2008; Shahack-Gross et al. 2014). Phytolith analysis in these dung deposits yielded very low concentrations (mostly below 0.3 million in $1 \mathrm{~g}$ of sediment) and phytolith morphotype analysis showed that most phytoliths originate from shrubs and wild grasses. Taken together, these lines of evidence indicate long-term corralling of livestock in the courtyards of the two studied sites with foddering based on free grazing only. Domestic cereals clearly did not form part of the herds' diet (data in Shahack-Gross et al. 2014). Below, we relate to each point of criticism with which we have thus far been confronted.

First, colleagues suggested that the phytolith indicator may not be well preserved, i.e. that phytoliths may have been dissolved with time. We addressed this possibility by carrying out a chemical test whose results unequivocally showed that phytoliths in the study area are well preserved (Shahack-Gross et al. 2014; see also Cabanes et al. 2011, 2012 for basic explanation of the chemical procedure). This is expected under the dry conditions in the Negev Highlands. Other lines of criticism relate to "common wisdom" notions:

(a) The location of the Iron IIA sites in an area with more water (Negev Highlands) than its surroundings indicates that settlements were established in areas that ensured success in dry farming (i.e. cultivation based on rain without need for irrigation). The fact that the study area receives only $\sim 100 \mathrm{~mm}$ of rainfall per year (in unpredictable patterns), while barley and wheat require at least 200 and $300 \mathrm{~mm}$ of water per growth season, respectively, in order to obtain economically successful yields (Arnon 1986), indicates that the only way to ensure successful yields would require growing these crops using irrigation systems such as wadi terraces. However, recent independent evidence based on optically stimulated luminescence (OSL) dating of wadi terraces demonstrates that irrigation systems were not present in the area prior to the late Roman period (Avni et al. 2012).

(b) The Iron IIA sites are located where later (Byzantine/Early Islamic) farmers built their settlements, indicating these were areas suitable for agriculture. This geographical observation is indeed correct, but in the absence of irrigation systems to intensify water availability to crops during the Iron IIA, this suggestion is irrelevant. 
(c) The Iron IIA sites are scattered, and with often only one or two buildings, which arguably indicates a settlement pattern that provides wide areas for cultivation on wadi beds. This critique, however, does not take into account the investment of labor required for cultivation and processing of crops. It is difficult to imagine one or two families being able to manage the labor needed for economically justified yields. Only microarchaeological work in the future at such small sites will be able to resolve this point.

(d) Grinding stones and small amounts of sickle blades have been found at Iron IIA sites, and these together with the few charred seeds of edible plants we found (see Shahack-Gross and Finkelstein 2008 ) indicate to some scholars that cultivation was conducted during the Iron IIA. We have already discussed this point in the past (Shahack-Gross and Finkelstein 2008), explaining that these items do not necessarily point to local cultivation as they can also indicate consumption of grains bought/ exchanged from neighboring areas.

(e) We have been asked whether herds could survive the lean months of the year if they are not foddered by a supplement, arguably through grazing on field stubble or stored cereals/grasses. We have previously reported, based on our own ethnoarchaeological work among Bedouins in the Negev Highlands, that the black goat, which is highly adapted to survival in this arid region, can feed on lichens during the lean months of the year (Shahack-Gross and Finkelstein 2008).

(f) Certain studies used pre-modern and modern Bedouin agricultural activities in the Negev Highlands as ethnographic analogs to archaeological societies of the area in historical periods (e.g. Bruins and van der Plicht 2007:492; Haiman 2012:46). We argue that Bedouins have used pre-existing irrigation systems available in the Negev Highlands since the Byzantine/Early Islamic period and hence their involvement in cereal cultivation cannot be used uncritically for archaeological inference.

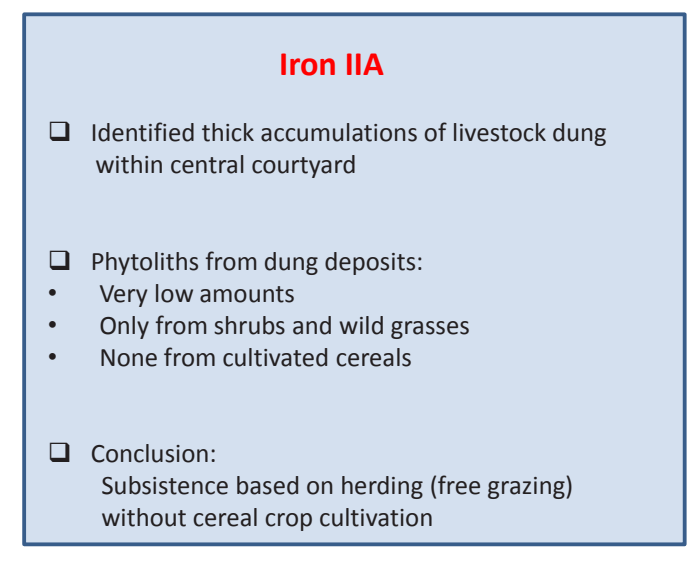

Additional evidence for subsistence practices: Trade (copper, pottery, dates, other)

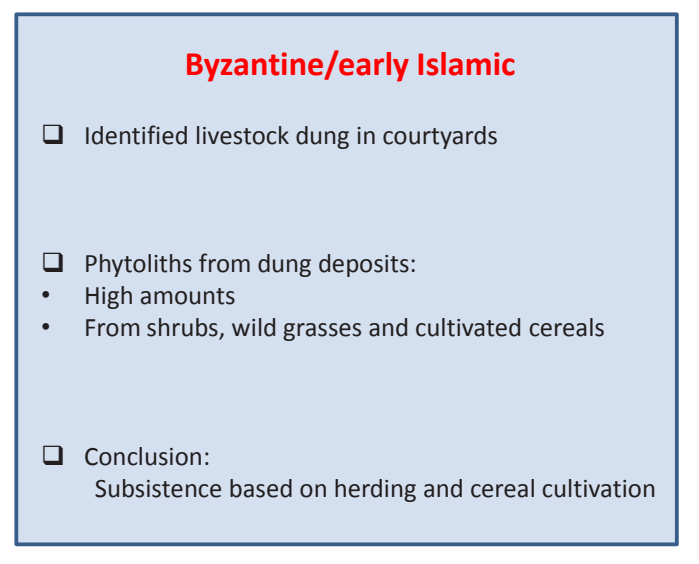

Additional evidence (textual) for subsistence practices: Fruit trees and cereal cultivation

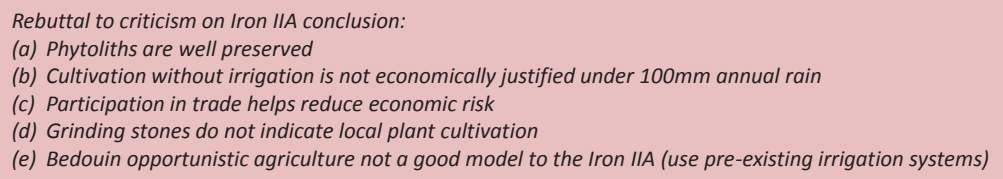

Figure 3 Summary of geoarchaeological evidence and the conclusions derived from them regarding subsistence practices in the Negev Highlands in the Iron IIA and Byzantine/early Islamic periods (boxes; the geoarchaeological evidence is presented in detail in Shahack-Gross and Finkelstein 2008; Shahack-Gross et al. 2014). Additional evidence for subsistence practices is given below the "Conclusion" points. At bottom, our rebuttal to the various points of criticism that our conclusion regarding subsistence practices in the Iron IIA has attracted. 
In conclusion, all lines of evidence point to absence of large-scale, and most probably even smallscale, cereal cultivation in the Negev Highlands during the Iron Age IIA settlement peak.

Results obtained from the study of two room and three courtyard contexts at a Byzantine/Early Islamic site-Wadi el-Mustayer-included evidence for cereal cultivation preserved in the concentrations and morphotype identities of phytoliths from degraded livestock dung deposits (details in Shahack-Gross et al. 2014). These results show the importance of using such sites as methodological controls, i.e. that phytolith analysis of well-preserved assemblages from dung indeed reflects human subsistence economy. The expected conclusion from this control study is therefore that cereal cultivation was carried out by the Byzantine/Early Islamic inhabitants in the Negev Highlands. The data, conclusions, and rebuttal to criticism are summarized in Figure 3.

\section{ADDITIONAL INFORMATION ON TRADE CONNECTIONS DURING THE IRON IIA}

Analysis of organic residues in late Iron I and Iron IIA pottery flasks found in Israel identified remains of cinnamon (Namdar et al. 2013). This commodity, which originated in India or another region of Southeast Asia, could have been transported to the Levant via several routes, including the one from Arabia and the Hejaz to southern Jordan, the Negev, and then the Mediterranean coast. The use of this route depended on availability of beasts of burden. Donkeys were utilized as burden animals as early as 5000 BP (Rossel et al. 2008), while recent work in southern Israel seems to indicate that the introduction of domestic camels to the region took place in the early Iron IIA - contemporary with the activity at the Negev sites (Sapir-Hen and Ben-Yosef 2013). In addition, in both Iron IIA sites studied by us, we identified many charred date palm pits, while palm phytoliths, produced in large quantities in palm leaves, were absent. A recent study by Cabanes and Shahack-Gross (forthcoming) shows that palm phytoliths are especially resistant to postdepositional dissolution. The absence of palm leaf phytoliths thus indicates that palm trees were not abundant in the Negev Highlands landscape or used for construction (e.g. roofing) at these sites. Based on these observations, we tentatively suggest that the relative abundance of charred date palm pits indicates that dates were not cultivated in the vicinity of the sites; rather, they were brought from afar via the desert trade routes, possibly from Arabia, where date palm trees have been cultivated in oases since the Bronze Age, 3000 BCE (Tengberg 2012). This suggestion requires further testing.

\section{SITING OF SETTLEMENTS IN THE IRON IIA NEGEV HIGHLANDS}

Past research suggested that the stone-built courtyard sites represent fortresses because most are located on topographic highs above wadi beds. Based on our familiarity with many Iron Age sites across the Negev Highlands, we suggest that the location of sites on topographic highs is not related exclusively to defense or other strategic considerations. We noted that almost all sites are built from limestone of the same geologic (Netzer) formation, which is characterized by thin beds $(20-50 \mathrm{~cm}$ thick) that naturally weather and crack into rectangular blocks (Figures $4 \mathrm{a}-\mathrm{b}$ ). We propose that site location was determined, at least in part, based on the availability of this raw material for construction. We note that Atar Haroa is exceptional in the rock type used for construction, namely flint from the geologic Mishash Formation, but this too is abundant in the site's proximity where it naturally weathers into large slabs (Figures 4c-d). While many consider stone-built structures as evidence of year-round settlement, we propose that the Iron IIA sites could have been built with rather low work investment and that the possibility that they served as seasonal/ephemeral habitation localities cannot be ruled out. 

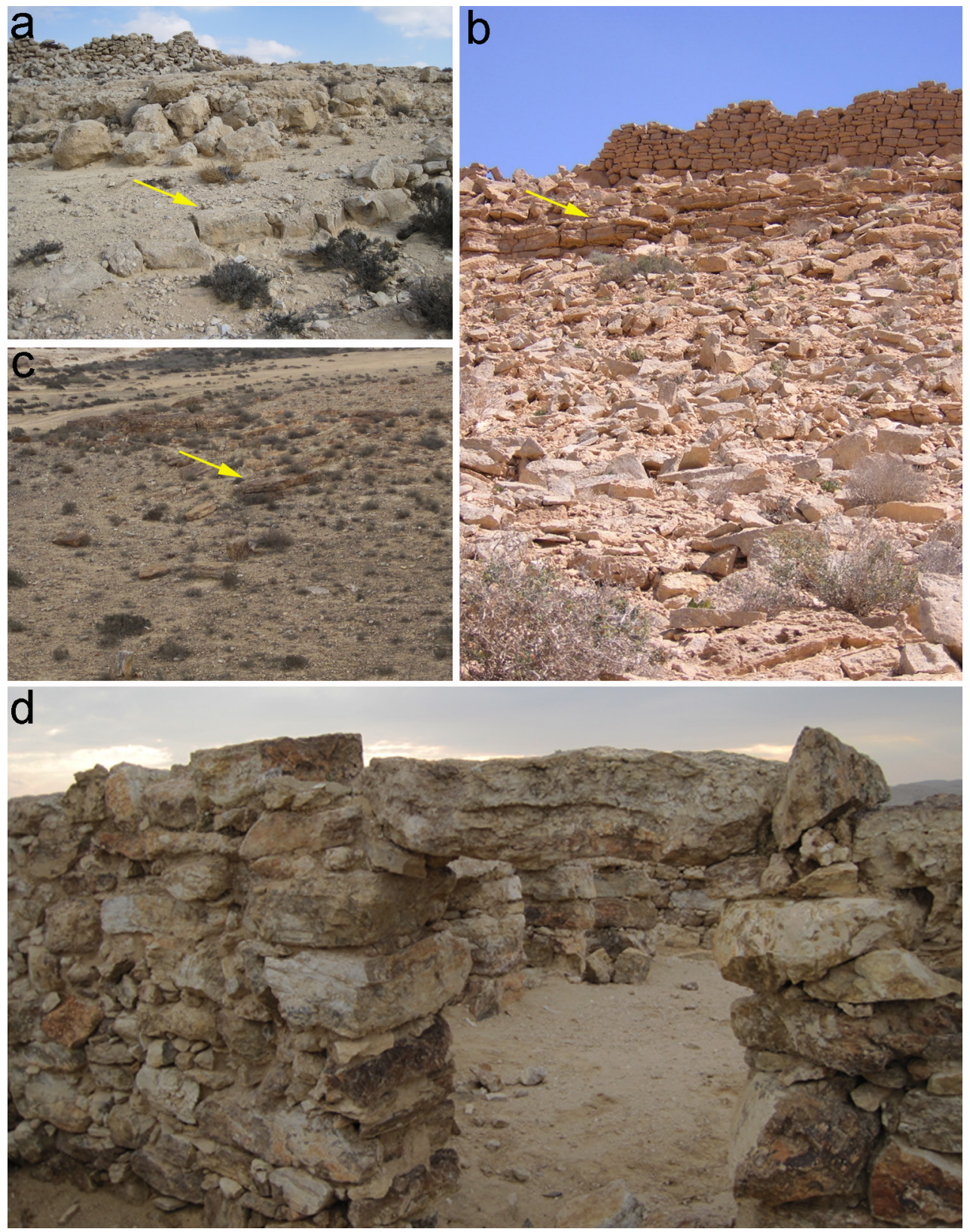

Figure 4 Construction materials in relation to their availability and accessibility: (a) well-bedded Netzer limestone showing natural weathering into blocks (arrow); in the background the site of Nahal Zena "fortress"; (b) wellbedded Netzer limestone (arrow) in the vicinity of Nahal Aqrab "fortress"; note the weathered limestone blocks along the slope; (c) weathered blocks of flint of the Mishash Formation along the slope adjacent to Atar Haroa; (d) well-preserved house at Atar Haroa constructed of local flint blocks.

\section{SYNTHESIS}

The new data obtained in our microarchaeological project provides evidence of a complex subsistence system that operated in the Negev Highlands during the Iron IIA and reached a peak following 
Shoshenq I's campaign to Canaan, which seemingly boosted a complex international trade system. Viewing the settlement oscillations in the Negev Highlands as solely representing ephemeral, limitedin-scale activities of small groups of pastoral nomads is somewhat misleading; the evidence presented here indicates that the Iron IIA settlement system was part of a larger apparatus that included copper production, possibly long-distance transportation of exotic spices, and perhaps trade of other commodities (e.g. seashells, asphalt/bitumen, ochre). It seems logical, then, to seek intervention of a major political power as a factor in the creation of such an international trade system. We emphasize that we do not contend that Shoshenq I ushered pastoralists to participate in an international trade system. Ethnographic studies of pastoralists consistently emphasize the flexibility of this subsistence strategy as one that readily adopts changes as a response to shifting social, political, and economic opportunities (e.g. Cribb 1991; Frachetti 2009). We suggest that Iron IIA pastoral groups actively participated in the international trade system as part of their risk-reducing, flexible survival strategy. Pastoralists may have taken part in copper production and trade. We note that participation in long- or short-distance trade can potentially be easy for nomadic pastoralists to adopt, as it can be conducted with accompanying herds, i.e. take advantage of involvement in trade while herds are being driven to various pasture lands. Or, certain members of the families/clans could have taken part in the copper industry in the Arabah and in transporting copper to the north, while other members of the same groups practiced short-range animal husbandry in the vicinity of their settlements in the Negev Highlands.

The Byzantine/Early Islamic wave of settlement in the Negev Highlands, too, was supported by strong out-of-the-desert political powers. A major unresolved question is why cereal cultivation was conducted during the Byzantine/Early Islamic period but not in the Iron Age IIA. Two possible answers may be posited, both understudied: (a) climate change and (b) technological innovation. The first option has not been well studied, at least not for the Negev, and future paleoclimatic research may lend insight into this question. The second option, and the more plausible one in our mind, is the advent of technological innovations in dry farming, which facilitated higher agricultural yield. The building of terraces along wadi beds is probably the best example of such technological innovation that penetrated into the Negev Highlands. Direct OSL dating conducted in the Negev Highlands indicates that terraced fields first appeared in the region during the late Roman or Byzantine/early Islamic period (Avni et al. 2012). This phenomenon may be tied to the prosperity of the RomanByzantine empires and later Arab polity, when the expansion of eastern irrigation techniques, such as the qanāt (identified in the southern Arabah, for example), across arid zones of the Middle East is evident (e.g. Watson 1974; Kamash 2012). Thus, a working hypothesis for future research may be that for the arid zones of the Levant - even in an improved ecological niche such as the Negev Highlands - sedentarization was a result of opportunities created by economic powers centered outside of the desert. In the Iron IIA, stimulation came from international trade, including the demand for Arabah copper following the decline of production in Cyprus (Knauf 1995:112-3), while in the Byzantine/Early Islamic period expansion of settlement into semi-arid margins (extensification sen$s u$ Porter et al. 2014) was probably related to population growth, intensification of production, and thus expansion of dry farming into marginal areas utilizing agrarian technological innovations such as terraces. Future research should thus focus on gaining a deeper understanding of other waves of settlement in the Negev Highlands, as well as a better understanding of the available agricultural and water management installations.

\section{STUDYING THE INTERMEDIATE BRONZE AGE WAVE OF SETTLEMENT}

The Intermediate Bronze Age in the Negev Highlands features a dense settlement system, including hundreds of sites of different size and nature, a large number of which were excavated in the late- 
20th century and produced primarily macroscopic data (Cohen 1999). Settlement during this period is characterized by both large central sites and smaller ephemeral sites. Scholars (e.g. Haiman 1996) interpreted the IBA settlement system in the Negev Highlands as part of a larger phenomenon distributed geographically between the Nile Delta, northern Sinai, the Negev Highlands, Wadi Arabah, and southern Transjordan, suggesting that it was driven by an external power (Egypt) interested in copper extraction, production, and trade, supplemented by limited pastoral nomadism (in the ephemeral sites) and marginal agriculture.

A recent radiometric project indicates that the Early Bronze Age came to an end $\sim 2500 \mathrm{BCE}$ (Regev et al. 2012), 200-300 yr earlier than the conventional opinion. This means that the Intermediate Bronze Age spans about 550 yr ( 2500-1950; for the latter datum see e.g. Bietak 2002), with the first $300 \mathrm{yr}$ or so corresponding to the Old Kingdom in Egypt - a developed empire, characterized by intensive trade, pyramid building, etc., and the last $250 \mathrm{yr}$ corresponding to the First Intermediate Period in Egypt, a time when Egypt disintegrated, and the very beginning of the Middle Kingdom. Based on this data, one could suggest that the central sites flourished as a result of copper trade with Egypt during the period of the Old Kingdom (for copper implements in these sites see Cohen 1999:260-5; for production in the area of Wadi Faynan see Levy et al. 2002), while the ephemeral sites coincide with the decline of this system and withdrawal of the Negev population to traditional pastoral activities during the First Intermediate Period. This hypothesis could be tested if a large data set of radiometric dates from this period would be available for the Negev Highlands; however, only a few such dates have been published thus far (Avner and Carmi 2001).

Based on the above, for this period, too, a microarchaeological approach is expected to yield new information regarding chronology and subsistence practices. A pilot test excavation at two IBA sites - the large, central site of Mashabe Sade and a small ephemeral site located $\sim 300 \mathrm{~m}$ east of it (Cohen 1999:117-30) — was conducted in 2013. Initial results designate that microscopic remains indicative of subsistence practices are meager in sediments sampled within and outside rooms at the central site (Dunseth 2013). New excavations are also being conducted at the site of Ein Ziq (Cohen 1999:137-88). Work is ongoing in order to gain a deeper understanding of the Intermediate Bronze Age settlement phenomenon.

\section{STUDYING AGRICULTURAL AND WATER MANAGEMENT INSTALLATIONS}

Agricultural and water management installations in the Negev Highlands include wadi terraces, built and rock-cut water cisterns, dams, canals, wells, silos, stone piles (tuleilat el-anab), and threshing floors (Evenari et al. 1982; Rubin 1990, 1991). Most research thus far has focused on macroscopic descriptions of these installations, and their chronological assignment was determined based on assumptions drawn from proximity to settlements datable through pottery finds. Systematic study so far has focused on terraced fields only (Avni et al. 2006, 2009, 2012). In the future, we intend to explore evidence for chronology and construction methods of water cisterns, as well as evidence for construction, tillage, manuring, and crops in field terraces. The ultimate goal is to integrate all lines of evidence with past climate and environmental conditions, political circumstances, and subsistence practices.

\section{CONCLUSION}

The Negev Highlands project described herein produced a significant impact on the archaeology of the south Levantine deserts. It demonstrated how integration of field archaeology and natural science-based methods can result in important new evidence related to interpretation of archaeological remains and historical reconstruction. It initiated a change of paradigm, including a change from 
the suggestion presented by one of us (Finkelstein 1995) regarding subsistence economy in these regions and hence their history.

\section{ACKNOWLEDGMENTS}

The work reported here was supported by the European Research Council 2008 Advanced Grant No. 229418, "Reconstructing Ancient Israel: The Exact and Life Sciences Perspective"; an Israel Science Foundation grant (642/05); the Chaim Katzman Archaeology Fund (Tel Aviv University); and an Ancient Israel "New Horizons" grant (Tel Aviv University). We wish to thank numerous students of Tel Aviv University and the Sede Boqer Field School for their help carrying out excavations. Special thanks to Salman Abu-Jelidan whose life experience herding in the area was insightful in all stages of our work. We also thank two anonymous reviewers for their useful comments.

\section{REFERENCES}

Arnon I. 1986. Agrometeorology. In: Halperin H, editor. The Encyclopedia of Agriculture. Tel Aviv: The Encyclopedia of Agriculture Press. p 250-81. In Hebrew.

Avner U, Carmi I. 2001. Settlement patterns in the southern Levant deserts during the 6th-3rd millennia BC: a revision based on ${ }^{14} \mathrm{C}$ dating. Radiocarbon 43(3):1203-16.

Avni Y, Porat N, Plakht J, Avni G. 2006. Geomorphic changes leading to natural desertification versus anthropogenic land conservation in an arid environment, the Negev Highlands, Israel. Geomorphology 82(3-4):177-200.

Avni G, Avni Y, Porat N. 2009. A new look at ancient agriculture in the Negev. Cathedra 133:13-44. In Hebrew.

Avni Y, Porat N, Avni G. 2012. Pre-farming environment and OSL chronology in the Negev Highlands, Israel Journal of Arid Environments 86:12-27.

Ben-Yosef E. 2010. Technology and social process: oscillations in Iron Age copper production and power in southern Jordan [PhD dissertation]. University of California, San Diego.

Bietak M. 2002. Relative and absolute chronology of the Middle Bronze Age: comments on the present state of research. In: Bietak M, editor. The Middle Bronze Age in the Levant. Vienna: Verlag der Osterreichischen Akademie der Wissenschaften. p 29-42.

Boaretto E, Finkelstein I, Shahack-Gross R. 2010. Radiocarbon results from the Iron IIA site of Atar Haroa in the Negev Highlands and their archaeological and historical implications. Radiocarbon 52(1):1-12.

Bruins HJ. 1986. Desert environment and agriculture in the Central Negev and Kadesh-Barnea during historical times [PhD dissertation]. University of Wageningen.

Bruins HJ, van der Plicht J. 2005. Desert settlement through the Iron Age. In: Levy T, editor. The Bible and Radiocarbon Dating. London: Equinox. p 349-66.

Bruins HJ, van der Plicht J. 2007. Radiocarbon dating the "Wilderness of Zin." Radiocarbon 49(2):481-97.
Cabanes D, Shahack-Gross R. Forthcoming. Understanding fossil phytolith preservation: the role of partial dissolution in paleoecology and archaeology. PLOS ONE.

Cabanes D, Weiner S, Shahack-Gross R. 2011. Stability of phytoliths in the archaeological record: a dissolution study of modern and fossil phytoliths. Journal of Archaeological Science 38(9):2480-90.

Cabanes D, Gadot Y, Cabanes M, Finkelstein I, Weiner S, Shahack-Gross R. 2012. Human impact around settlement sites: a phytolith and mineralogical study for assessing site boundaries, phytolith preservation, and implications for spatial reconstructions using plant remains. Journal of Archaeological Science 39(8):2697-705.

Cohen R. 1979. The Iron Age fortresses in the Central Negev. Bulletin of the American Schools for Oriental Research 236:63-75.

Cohen R. 1999. Ancient Settlement of the Central Negev. Volume 1: The Chalcolithic Period, The Early Bronze Age and the Middle Bronze Age I. Jerusalem: Israel Antiquities Authority.

Cohen R, Cohen-Amin R. 2004. Ancient Settlement of the Negev Highlands. Volume II: The Iron Age and the Persian Period. Jerusalem: Israel Antiquities Authority.

Cribb R. 1991. Nomads in Archaeology. Cambridge: Cambridge University Press.

Dunseth Z. 2013. Subsistence practices in the Negev Highlands during the Intermediate Bronze Age: a microarchaeological investigation at Mashabe Sade [MA thesis]. Tel Aviv University.

Evenari M, Shanan L, Tadmor N. 1982. The Negev: The Challenge of a Desert. Cambridge: Harvard University Press.

Finkelstein I. 1988. Arabian trade and socio-political conditions in the Negev in the twelfth-eleventh centuries B.C.E. Journal of Near Eastern Studies 47(4):241-52.

Finkelstein I. 1995. Living on the Fringe: The Archaeology and History of the Negev, Sinai and Neighbouring Regions in the Bronze and Iron Ages. Sheffield: Academic Press. 
Frachetti M. 2009. Pastoralist Landscapes and Social Interaction in Bronze Age Eurasia. Berkeley: University of California Press.

Goldberg P. 1984. Late Quaternary history of Qadesh Barnea, northeastern Sinai. Zeitschrift fur Geomorphologie N.F. 28:193-217.

Haiman M. 1989. Preliminary report on the Western Negev Highlands emergency survey. Israel Exploration Journal 39:173-91.

Haiman M. 1994. The Iron Age II sites of the Negev Highlands. Israel Exploration Journal 44:36-61.

Haiman M. 1996. Early Bronze Age IV settlement pattern of the Negev and Sinai deserts: view from small marginal temporary sites. Bulletin of the American Schools for Oriental Research 303:1-31.

Haiman M. 2012. Dating the agricultural terraces in the southern Levantine deserts - the spatial-contextual argument. Journal of Arid Environments 86:43-9.

Herzog Z, Singer-Avitz L. 2004. Redefining the centre: the emergence of state in Judah. Tel Aviv 31(2):209 44.

Jasmin M. 2006. The emergence and first development of the Arabian trade across the Wadi Arabah. In: Bienkowski P, Galor K, editors. Crossing the Rift: Resources, Routes, Settlement Patterns and Interaction in the Wadi Arabah. Oxford: Oxford University Press. p 143-50.

Kamash Z. 2012. Irrigation technology, society and environment in the Roman Near East. Journal of Arid Environments 86:65-74.

Knauf EA. 1995. Edom: the social and economic history. In: Edelman DV, editor. You Shall Not Abhor an Edomite for He is Your Brother: Edom and Seir in History and Tradition. Atlanta: Scholars Press. p 93-117.

Levy T. 2009. Pastoral nomads and Iron Age metal production in Ancient Edom. In: Szuchman J, editor. Nomads, Tribes and the State in the Ancient Near East: Cross-Disciplinary Perspectives. Chicago: University of Chicago Press. p 147-77.

Levy TE, Adams RB, Hauptmann A, Prange M, Schmitt-Strecker S, Najjar M. 2002. Early Bronze Age metallurgy: a newly discovered copper manufactory in southern Jordan. Antiquity 76(292):42537.

Martin MAS, Eliyahu-Behar A, Anenburg M, Goren Y, Finkelstein I. 2013. Iron IIA slag-tempered pottery in the Negev Highlands, Israel. Journal of Archaeological Science 40(10):3777-92.

Namdar D, Gilboa A, Neumann R, Finkelstein I, Weiner S. 2013. Cinnamaldehyde in early Iron Age Phoenician flasks raises the possibility of Levantine trade with South East Asia. Mediterranean Archaeology and Archaeometry 13(2):1-19.

Porter BW, Routledge BE, Simmons EM, Lev-Tov JSE. 2014. Extensification in a Mediterranean semi-arid marginal zone: an archaeological case study from early Iron Age Jordan's eastern Karak Plateau. Journal of Arid Environments 104:132-48.

Regev J, de Miroschedji P, Greenberg R, Braun E, Greenhut Z, Boaretto E. 2012. Chronology of the Early Bronze Age in the southern Levant: new analysis for a high chronology. Radiocarbon 54(3-4):525-66.

Rosen SA. 1987. Demographic trends in the Negev Highlands: preliminary results of the emergency survey. Bulletin of the American Schools for Oriental Research 266:45-58.

Rossel S, Marshall F, Peters J, Pilgram T, Adams MD, O'Connor D. 2008. Domestication of the donkey: timing, processes, and indicators. Proceedings of the National Academy of Sciences of the USA 105(10):3715-20.

Rubin R. 1990. The Negev as Settled Land: Urbanization and Settlement in the Desert in the Byzantine Period. Jerusalem: Yad Ben Zvi. In Hebrew.

Rubin R. 1991. Settlement and agriculture on an ancient desert frontier. Geographical Review 81:197-205.

Sapir-Hen L, Ben-Yosef E. 2013. The introduction of domestic camels to the southern Levant: evidence from the Aravah Valley. Tel Aviv 40(2):277-85.

Sebbane M, Ilan O, Avner U, Ilan D. 1993. The dating of Early Bronze Age settlements in the Negev and Sinai. Tel Aviv 20:41-54.

Segal I, Roman I, Cohen R, Brenner IB. 1996-1997. Chemical and metallurgical study of 'Ein Ziq and Be'er Resisim ingots. Arx: World Journal of Prehistoric and Ancient Studies 2-3:43-51.

Shahack-Gross R. 2011. Herbivorous livestock dung: formation, taphonomy, methods for identification, and archaeological implications. Journal of Archaeological Science 38(2):205-18.

Shahack-Gross R, Finkelstein I. 2008. Subsistence practices in an arid environment: a geoarchaeological investigation in an Iron Age site, the Negev Highlands, Israel. Journal of Archaeological Science 35(4):965-82.

Shahack-Gross R, Marshall F, Weiner S. 2003. Geoethnoarchaeology of pastoral sites: the identification of livestock enclosures in abandoned Maasai settlements. Journal of Archaeological Science 30(4):439-59.

Shahack-Gross R, Boaretto E, Cabanes D, Katz O, Finkelstein I. 2014. Subsistence economy in the Negev Highlands: the Iron Age and the Byzantine/Early Islamic period. Levant 46(1):98-117.

Tengberg M. 2012. Beginnings and early history of date palm garden cultivation in the Middle East. Journal of Arid Environments 86:139-47.

Watson AM. 1974. The Arab agricultural revolution and its diffusion, 700-1100. Journal of Economic History 34(1):8-35.

Weiner S. 2010. Microarchaeology: Beyond the Visible Archaeological Record. Cambridge: Cambridge University Press. 